\title{
Gendered sexual risk patterns and polygamy among HIV sero-discordant couples in Uganda
}

Sarah Khanakwa*, Moses Ngolobe, David Moore, Robert Mwesigwa, Josephine Birungi, Rachel King, Kate Shannon

From 17th International Symposium on HIV and Emerging Infectious Diseases (ISHEID)

Marseille, France. 23-25 May 2012

\section{Background}

Multiple sexual partnerships and HIV sero-discordant relationships are among the most at-risk for HIV transmission. Polygamy is a common form of multiple-partnered relationships in Eastern Uganda. We investigated the association between HIV risk patterns and polygamy among HIV sero-discordant couples at The AIDS Support Organization in Jinja, Uganda Methods Participants were enrollees in a prospective cohort of HIV sero-discordant couples, the Highly Active Antiretroviral therapy as Prevention (HAARP) Study at TASO Jinja. Descriptive and bivariate analyses to compare sexual risk patterns among HIV sero-discordant men; in polygamous as compared to single-spouse relationship.

\section{Results}

Polygamous Vs Single-spouse couples $\geq 2$ wives 1 wife $\mathrm{P}$ value $\mathrm{N}=24156185$ Male HIV+ve 38 (68\%) 99 (54\%) 0.065 Male-controlled sexual decision making $34(61 \%)$ 66 (36\%) 0.001 Male-controlled condom use 33 (59\%) $51(28 \%)<0.001$ Condom last time had sex $45(80 \%)$ 128 (69\%) 0.086 Financial support $45(80 \%) 152(82 \%)$ 1.00 HIV positive partner on ART 24 (37\%) 88 (48\%) 0.143 Median age (IQR) $44(39-50) 43(37-50) 0.451$.

\section{Conclusion}

This study demonstrates continued gendered risks for women in HIV sero-discordant relationships in subSaharan Africa. In particular, men with 2 or more wives are more likely to make decisions about when to have sex or when to use a condom. However, we found no differences in condom use at last sex by polygamy status.

* Correspondence: khanakwas@yahoo.com

Aids Support Organization (Taso) Uganda, Jinja, Uganda
Published: 25 May 2012

doi:10.1186/1742-4690-9-S1-P103

Cite this article as: Khanakwa et al.: Gendered sexual risk patterns and polygamy among HIV sero-discordant couples in Uganda. Retrovirology 2012 9(Suppl 1):P103.
Submit your next manuscript to BioMed Central and take full advantage of:

- Convenient online submission

- Thorough peer review

- No space constraints or color figure charges

- Immediate publication on acceptance

- Inclusion in PubMed, CAS, Scopus and Google Scholar

- Research which is freely available for redistribution 